\title{
CORROSION BEHAVIOR AND THE WEAK-MAGNETIC-FIELD EFFECT OF ALUMINUM PACKAGING PAPER
}

\author{
VPLIV ŠIBKEGA MAGNETNEGA POLJA NA KOROZIJO \\ ALUMINIJEVE EMBALAŽNE FOLIJE
}

\author{
Nacer Zazi ${ }^{1}$, Jean-Paul Chopart ${ }^{2}$, Ali Bilek ${ }^{1}$ \\ ${ }^{1}$ University Mouloud Mammeri of Tizi-Ouzou, Faculty of Construction Engineering, Department of Mechanical Engineering (LMSE), \\ B.P.17 RP Tizi-Ouzou, Algeria \\ ${ }^{2}$ Université de Reims Champagne Ardenne, LISM EA 4695 UFR SEN, BP1039, Moulin de la Housse, 51687 Reims, Cedex, France \\ zazinacer@yahoo.fr
}

Prejem rokopisa - received: 2014-05-21; sprejem za objavo - accepted for publication: 2015-04-13

doi: $10.17222 /$ mit. 2014.083

\begin{abstract}
Aluminum can be absorbed through the digestive system from water and drinks and the food that contains natural traces and processed food or the food cooked in aluminum cookware. Some studies show that the people exposed to high levels of aluminum may develop kidney, bone and brain diseases. Aluminum foil (AlFeSi) is daily used as packaging for food and drugs stored in the refrigerator where an electric motor induces a magnetic field of a few microteslas. The purpose of this work is to study the corrosion behavior of various aluminum packaging foils and the effect of a weak magnetic field on the morphology and the corrosion kinetics in the $0.3 \%$ and $3 \%$ of mass fractions of $\mathrm{NaCl}$ solutions. The mean results for various aluminum packaging foils show that localized corrosion is controlled by the electrochemical potentials of different phases constituting the aluminum foil and the concentration of the precipitates from the other phases. The morphology and the corrosion kinetics of aluminum packaging foil in the $0.3 \%$ and $3 \%$ of mass fractions of $\mathrm{NaCl}$ solutions are different with and without an application of a weak magnetic field. Electrochemical tests applied to cheese packaging paper show that the introduction of a magnetic field decreases the polarization resistance, the potential of passivation and the value of the open-circuit potential at the beginning of the corrosion; however, its passivation-current density increases at the beginning of the corrosion. The values of the open-circuit potential with and without a weak magnetic field are the same after thirty days of corrosion.
\end{abstract}

Keywords: aluminum packaging foil, weak magnetic field, aluminum alloys, corrosion, passivation

\begin{abstract}
Aluminij se lahko absorbira v prebavni sistem iz vode in pijač in iz hrane, ki vsebuje naravne sledi ter obdelane hrane ali hrane, kuhane v aluminijasti posodi. Nekatere študije kažejo, da ljudje izpostavljeni visokemu nivoju aluminija, lahko zbolijo na ledvicah, kosteh in možganih. Aluminijeva folija (AlFeSi), ki se dnevno uporablja kot embalaža za hrano in zdravila, se hrani v hladilniku, kjer elektromotor inducira magnetno polje jakosti nekaj mikroteslov. Namen študije je predstavitev korozijskega obnašanja različnih aluminijevih embalažnih folij in vpliv šibkega magnetnega polja na morfologijo in kinetiko korozije v $0,3 \%$ in $3 \%$ raztopini $\mathrm{NaCl}$. Rezultati kažejo, da je pri različnih aluminijevih folijah lokalna korozija kontrolirana z elektrokemijskim potencialom različnih faz, ki sestavljajo aluminijevo folijo in s koncentracijo izločkov drugih faz. Morfologija in kinetika korozije aluminijevih embalažnih folij v $0,3 \%$ in $3 \%$ raztopini $\mathrm{NaCl}$, sta različni pri prisotnosti ali odsotnosti šibkega magnetnega polja. Elektrokemijski preizkusi, izvršeni na ovojni foliji za sir, so pokazali, da prisotnost magnetnega polja na začetku korozije zmanjša polarizacijsko odpornost, potencial pasivacije in vrednost potenciala odprtega kroga, vendar pa gostota pasivacijskega toka narašča. Vrednost potenciala odprtega kroga je po tridesetih dneh enaka, ob prisotnosti ali odsotnosti šibkega magnetnega polja.

Ključne besede: aluminijeva embalažna folija, šibko magnetno polje, aluminijeve zlitine, korozija, pasivacija
\end{abstract}

\section{INTRODUCTION}

Aluminums, when combined with various elements and subjected to various thermomechanical treatments, exhibit considerable advantages, such as good mechanical properties. However, the use of these alloys does not remove any disadvantage; for example, various types of corrosion can appear. These alloys are used as packaging for foodstuffs, drugs, and in the kitchen utensils for short, average or long durations because of their low density, good formability and excellent corrosion resistance in the air environment. ${ }^{1-3}$ The corrosion resistance of aluminum is directly related to the formation of an alumina oxide or hydroxide on the material surface, inducing a relative passivation of these alloys. This resistance is limited to the environments where these oxides are slightly soluble at the $\mathrm{pH}$ values of $4-9 .{ }^{1}$
Aluminum alloys are sensitive to localized corrosion in aggressive environments containing chlorides such as food and drugs. Several theories on localized corrosion were closely connected to the passive oxide-film rupture. In aluminums, localized corrosion appears when aggressive ions such as chlorides break the protection by locally attacking the passive layer. The chlorides generate the corrosion surrounding the defect oxide film in surface heterogeneities, such as crevices, precipitates and intermetallic particles. ${ }^{4-8}$ These heterogeneities create a distribution of cathodic and anodic areas across the alloy surface and then various forms of localized corrosion take place. ${ }^{5}$

Aluminum of the first fusion contains $0.1 \%$ iron, which is higher than the limit solubility of iron in aluminum at room temperature. Moreover, only few products are elaborated from aluminum of the first 
fusion, while great quantities of recycled-aluminum alloys are used in the manufactured products. This increases the iron content in aluminum alloys, so iron phases are formed. ${ }^{9}$

An iron phase is cathodic and nobler than aluminum; its presence in an aluminum alloy affects the kinetics of the aluminum anodic dissolution and makes it a significant factor of the localized aluminum-alloy corrosion. ${ }^{9}$ The richer the phases are in iron, the more they become favorable sites for cathodic reactions and their surroundings are adequate positions for anodic reactions and localized corrosion.

Others impurities are soluble in aluminum because their solubility limits are higher than their concentrations in aluminum.

The presence of different intermetallic precipitates in aluminum-matrix alloys increases the mechanical properties and their susceptibility to corrosion. ${ }^{10}$

Aluminum alloys used for kitchen utensils come from recycled worn parts of cars, aircraft, gutters, wires, drink cans, etc. Their chemical analysis revealed the presence of heavy elements such as $\mathrm{Cd}, \mathrm{Co}, \mathrm{Cr}, \mathrm{Pb}, \mathrm{Ni}$ and $\mathrm{Zn}$. These utensils can contaminate man's food chain and lead to a bio-accumulation of heavy metals in the vital parts of the human body such as liver, kidneys, spleen. ${ }^{1-12}$ When the concentration of these elements is higher than their solubility limit, they modify the electrochemical potential of the material surface by generating new intermetallic particles or joining the chemical compositions of the existing intermetallic particles.

Magnetic fields are powerful scientific tools for metal-deposition or dissolution studies. The presence of a magnetic field improves the mass transfer of an electrochemical system, the quality of the deposit and the influence of the corrosion phenomena. ${ }^{13}$

Aluminum foil is daily used as packaging for food and drugs stored in a refrigerator where an electric motor induces a magnetic field of a few microteslas. ${ }^{14}$

The purpose of this study is to examine the corrosion phenomena of various aluminum foils intended for food and drug packaging and aluminum kinetic dissolution. The effect of a week permanent magnetic field on the morphology and corrosion kinetics of an aluminum foil in a $\mathrm{NaCl}$ solution is also examined.

\section{MATERIALS AND METHODS}

Various aluminum packaging foils were tested in our experiments using light microscopy, scanning electronic microscopy, X-ray diffraction and corrosion tests. Batches of aluminum foil intended for cheese, chocolate, drug and foodstuff packaging in rolls were used as samples.

The nominal chemical composition of different aluminum packaging paper is given in Table $\mathbf{1}$.

The corrosion measurements were undertaken at room temperature. Samples of $1 \mathrm{~cm}^{2}(\varnothing=11.28 \mathrm{~mm})$ were immersed in chloride sodium solutions of the $0.3 \%$ and $3 \%$ of mass fractions of $\mathrm{NaCl}$. The four-electrode method was used. A saturated calomel electrode (SCE) was used as the reference electrode. The two auxiliary electrodes were in graphite.

Open-circuit potential and current potential were obtained by means of an EGG-Princeton 263 potentiostat. Before determining the layout of the polarization curves, the working electrode was polarized at $-0.8 \mathrm{~V}$. To obtain the polarization curves, we applied a potential that evolved to ascending values, passing from the cathodic domain towards the anodic domain. The samples intended for electrochemical tests, microscopic examination and X-ray diffraction were not polished in order to keep the surface of the aluminum foil appropriate for its daily use.

The microstructures and surface morphologies of corroded and non-corroded samples were characterized with light microscopy and scanning electron microscopy (Philips Esem-XL30, tungsten filament). Prior to microscopic characterization, the corroded samples were rinsed with distilled water and dried in desiccators.

The chemical composition of the aluminum foil surface was characterized with a JEOL JSM 6460LA microscope coupled with an EDS JEL 1300 microprobe.

The corrosion tests were carried out by immersing the aluminum packaging-foil samples in the $0.3 \%$ and $3 \%$ of mass fractions of $\mathrm{NaCl}$ solutions at $\mathrm{pH}=7$ with and without a week permanent magnetic field (42 mT). A magnet with a ring shape was positioned near the sample surfaces. The same distance was kept between the working electrodes and the magnet for all samples.

Micro-hardness measurements were taken with a Zwick Roell ZHV $1 \mathrm{M}$ tester. The HV scale, under a load of $5 \mathrm{~g}$ was chosen for this testing. Five measurements were taken for each sample.

Table 1: Chemical compositions of various packaging foils

Tabela 1: Kemijska sestava različnih embalažnih folij

\begin{tabular}{|c|c|c|c|c|c|c|c|c|c|c|c|}
\hline $\begin{array}{c}\text { Elements/Aluminum } \\
\text { packaging foil for: }\end{array}$ & $\mathrm{Al}$ & $\mathrm{Si}$ & $\mathrm{Fe}$ & $\mathrm{Mg}$ & $\mathrm{Cu}$ & $\mathrm{Mn}$ & $\mathrm{V}$ & $\mathrm{Cr}$ & $\mathrm{Ti}$ & $\mathrm{Zn}$ & $\mathrm{Other}$ \\
\hline domestic use & 99.344 & 0.208 & 0.253 & 0.040 & 0.038 & 0.035 & 0.020 & 0.012 & 0.006 & 0.004 & 0.040 \\
\hline drug & 98.100 & 0.700 & 0.820 & 0.050 & 0.095 & 0.014 & 0.020 & 0.022 & 0.050 & 0.086 & 0.043 \\
\hline chocolate & 99.271 & 0.300 & 0.150 & 0.035 & 0.025 & 0.022 & 0.033 & 0.005 & 0.040 & 0.026 & 0.093 \\
\hline cheese & 98.300 & 0.630 & 0.575 & 0.083 & 0.072 & 0.026 & 0.011 & 0.016 & 0.042 & 0.076 & 0.169 \\
\hline
\end{tabular}


The X-ray spectrum was obtained with a Bruker AXS D8 Advance diffractometer.

\section{RESULTS AND DISCUSSION}

The Vickers micro-hardness results obtained for several batches of aluminum packaging foil for cheese (Table 2) show the changes between the batches. This means that the mechanical and chemical properties of the aluminum foil surface change from one batch to another. ${ }^{7,15}$ Consequently, the morphology and corrosion kinetics are expected to differ from one batch to another. ${ }^{7,15}$

Table 2: Hardness measurements of aluminum packaging foils Tabela 2: Meritve trdote aluminijevih embalažnih folij

\begin{tabular}{|c|c|c|c|}
\hline $\begin{array}{c}\text { Sample of the cheese } \\
\text { aluminum packaging foil }\end{array}$ & 1 & 2 & 3 \\
\hline $\begin{array}{c}\text { Vickers micro-hardness } \\
\left(25^{\circ} \mathrm{C}\right)\end{array}$ & 16.2 & 19.4 & 14.8 \\
\hline
\end{tabular}

The aluminum packaging foil under light and scanning electron microscopy reveals an aluminum solid-solution matrix, intermetallic particles and or precipitates (Figures $\mathbf{1}$ to $\mathbf{3}$ ). The microstructure of a non-polished aluminum drug-packaging foil shows the presence of furrows oriented in one direction (Figure 1d). Except for certain batches of aluminum cheesepackaging foil, no furrows were observed (Figures 1a to 1c). This is probably due to the wear of the rolling mills during the manufacture of aluminum cheese-packaging foil. The furrows on the surface constitute corrosivesolution storage zones that induce differential aeration. This phenomenon causes changes in the morphology and the kinetics of corrosion and increases the dissolution of aluminum and other anodic metals. Several precipitates were seen in the aluminum drug-packaging foil (Figure 2).
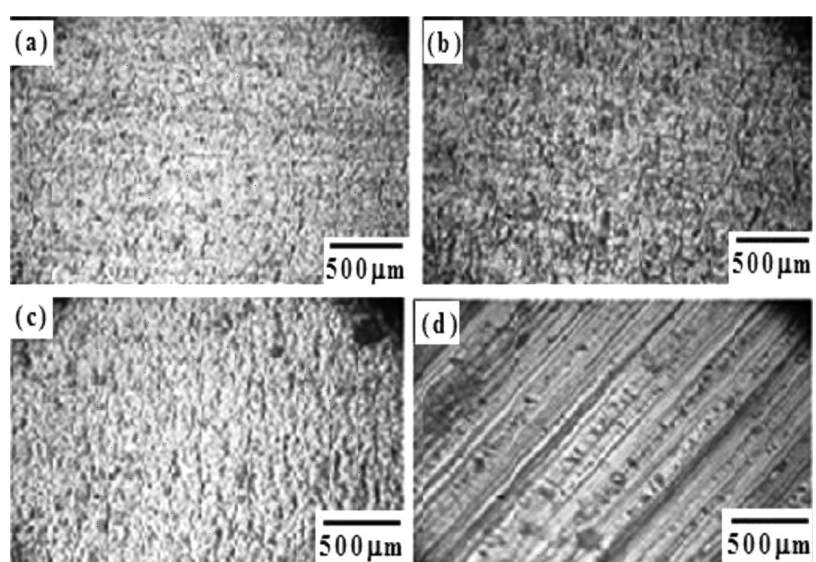

Figure 1: Microstructure of the aluminum packaging foil: a) for domestic use, b) for chocolate, c) for cheese, d) for drugs

Slika 1: Mikrostruktura aluminijeve folije: a) za gospodinjstvo, b) za čokolado, c) za sir, d) za zdravila
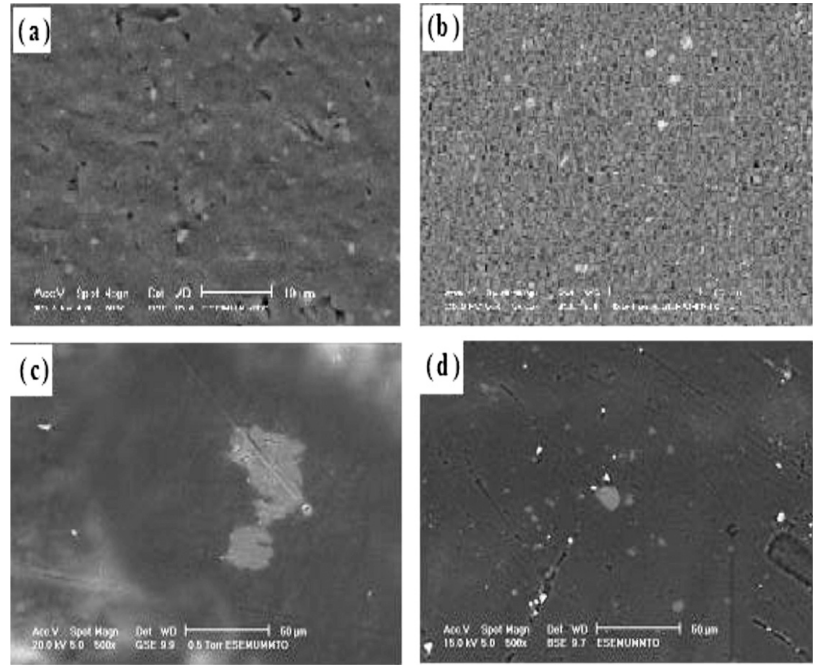

Figure 2: Micrographs of scanning electron microscopy (SEM) showing the structure of aluminum: a) for domestic use, b) for chocolate, c) for cheese, d) for drugs

Slika 2: SEM-posnetki z vrstičnim elektronskim mikroskopom (SEM), ki kaže strukturo aluminija: a) za gospodinjstvo, b) za čokolado, c) za sir, d) za zdravila

The thermomechanical history varies between different aluminum foils. On the surface perpendicular to a rolled surface, the grains appear to be small for all the aluminum foils (Figure 3). The aluminum packaging foils do not have the same thickness and the same grain size (Figure 3). The X-ray spectrum of the aluminum packaging foil intended for drugs (Figure 4) and the texture-calculating method of Muresan et al. ${ }^{16}$ show the presence of a pseudo-texture because the rates of the (220 and 311) plans exceed $50 \%$. This is probably due to the mechanical treatments (cold rolling) during its elaboration. This can influence the corrosion phenomena and support an oriented corrosion with privileged plans.
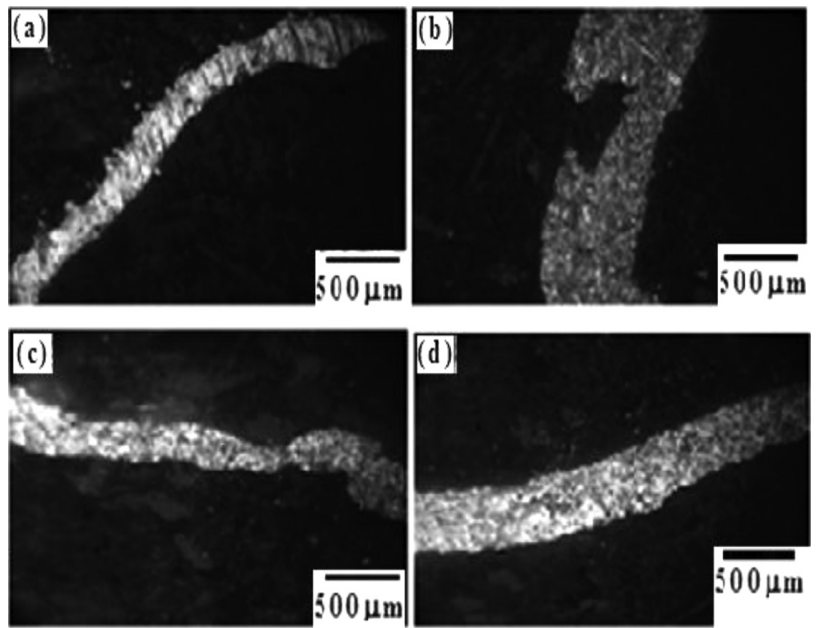

Figure 3: Perpendicular face of rolled aluminum foil for: a) domestic use, b) chocolate, c) cheese and d) drugs

Slika 3: Prečni presek valjane aluminijeve embalažne folije za: a) gospodinjstvo, b) čokolado, c) sir in d) zdravila 


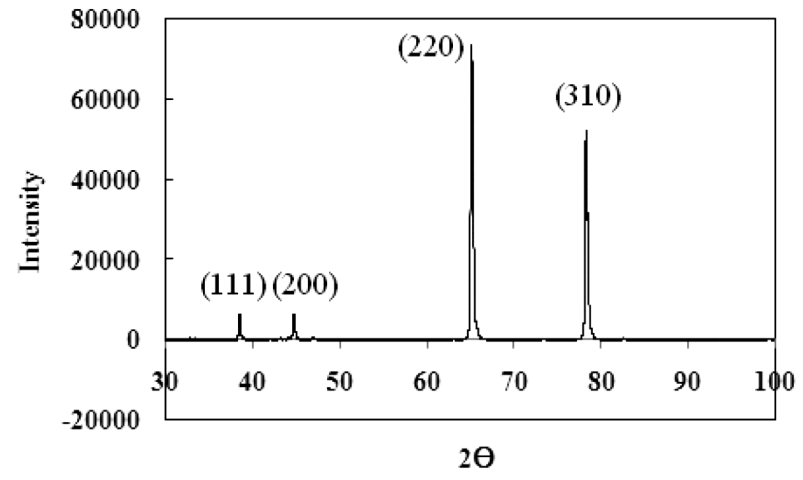

Figure 4: X-ray spectrum of the aluminum packaging foil for drugs Slika 4: Rentgenogram aluminijeve embalažne folije za zdravila

The corrosion investigation has been studied in the presence and absence of magnetic field (Table 3, Figure 5 and $\mathbf{6})$.

\subsection{Corrosion morphology of aluminum packaging foil}

In order to correlate the accelerated electrochemical tests with the real corrosion phenomena of aluminum packaging foil, long-term tests involving an immersion in the $0.3 \%$ of mass fractions of $\mathrm{NaCl}$ solution were realized. Figure 5 shows the corroded surfaces of various aluminum packaging foils intended for domestic use, chocolate, cheese and drugs under an light microscope after $30 \mathrm{~d}$ of the immersion in $0.3 \%$ of mass fractions of $\mathrm{NaCl}$ at room temperature. On various aluminum packaging foils, a local destruction of the passive film was observed, having a localized-corrosion appearance. No apparent corrosion was observed on
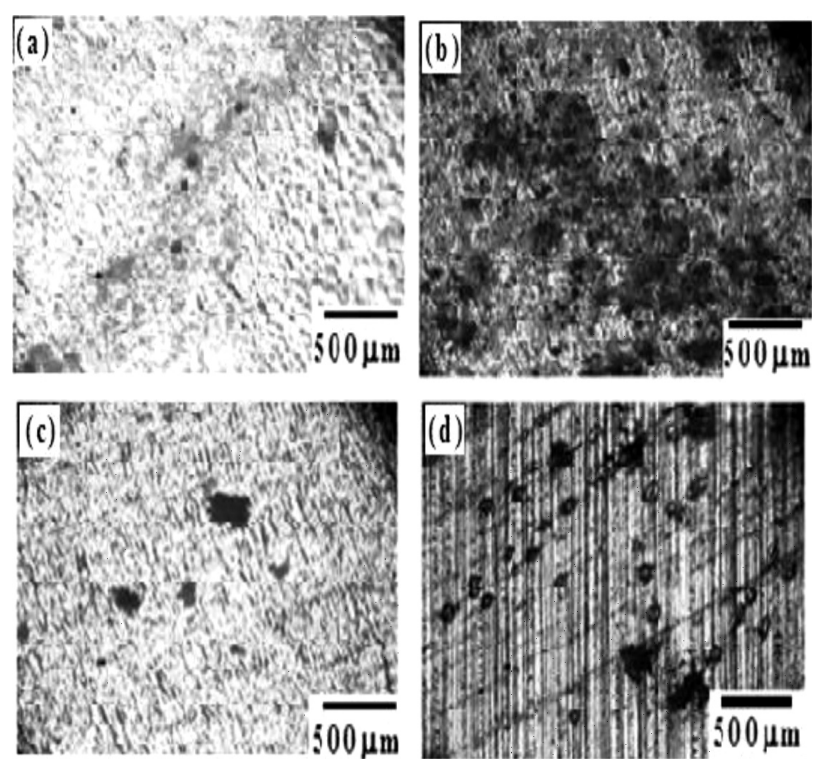

Figure 5: Microstructures of various aluminum packaging foils for: a) domestic use, b) chocolate, c) cheese and d) drugs, after $30 \mathrm{~d}$ of immersion in a $0.3 \% \mathrm{NaCl}$ solution in the absence of the magnetic field

Slika 5: Mikrostruktura različnih aluminijevih embalažnih folij za: a) gospodinjstvo, b) čokolado, c) sir in d) zdravila, po 30 dneh namakanja v raztopini $0,3 \% \mathrm{NaCl} v$ odsotnosti magnetnega polja
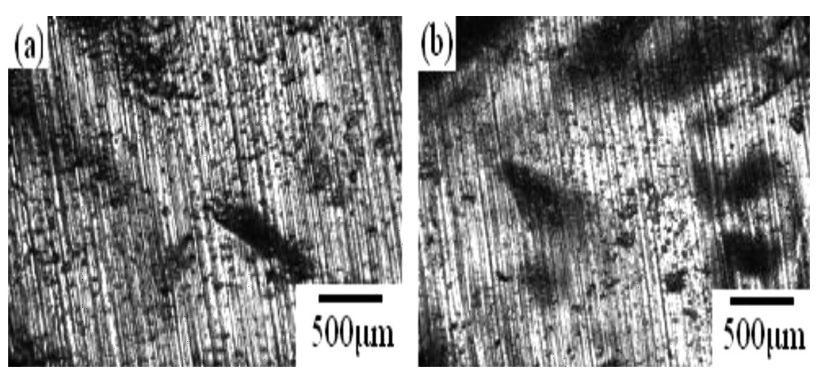

Figure 6: Microstructures of other batches of aluminum packaging after $8 \mathrm{~d}$ of immersion in a $3 \%$ of mass fraction of $\mathrm{NaCl}$ solution: a) in the absence of the magnetic field, b) in the presence of a weak magnetic field

Slika 6: Mikrostrukturi drugih serij aluminijevih folij po 8 dneh namakanja v $3 \%$ raztopini $\mathrm{NaCl}$ : a) v odsotnosti magnetnega polja, b) ob prisotnosti šibkega magnetnega polja

domestic aluminum packaging foil (Figure 5a). The surfaces of the aluminum packaging foils intended for chocolate and drugs appear to be more corroded (Figures $\mathbf{5 b}$ and $\mathbf{5 d}$ ). The corrosion of the packaging foil for drugs is oriented according to the privileged direction (Figure 5d). The corrosion on the aluminum packaging foils seems to be more controlled by the precipitate and intermetallic-particle densities (Figures 1, 2 and 5).

The electrochemical responses of these alloys are related to the precipitates and intermetallic particles distributed heterogeneously on the surface, to the impurities in the aluminum packaging foils and to the chloride ions in the solution (Figures 5 and 6).

Table 3: Corrosion potential and polarization resistance of the aluminum packaging foil for cheese in the presence and absence of the magnetic field for a sample area of $1 \mathrm{~cm}^{2}$ in a $0.3 \%$ of mass fractions of $\mathrm{NaCl}$ medium

Tabela 3: Korozijski potencial in polarizacijska upornost aluminijeve embalažne folije za sir ob prisotnosti in odsotnosti magnetnega polja za vzorec s površino $1 \mathrm{~cm}^{2}$ v $0,3 \%$ raztopini $\mathrm{NaCl}$

\begin{tabular}{|l|c|c|}
\hline \multicolumn{1}{|c|}{ Sample } & $\begin{array}{c}\text { Corrosion } \\
\text { potential } \\
(\mathrm{mV})\end{array}$ & $\begin{array}{c}\text { Polarization } \\
\text { resistance } \\
(\mathrm{k} \Omega)\end{array}$ \\
\hline $\begin{array}{l}\text { Presence of a weak magnetic field } \\
\text { after 1 h of immersion }\end{array}$ & -560 & 4 \\
\hline $\begin{array}{l}\text { Presence of a weak magnetic field } \\
\text { after 30 d of immersion }\end{array}$ & -220 & 20 \\
\hline $\begin{array}{l}\text { Absence of the magnetic field } \\
\text { after 1 h of immersion }\end{array}$ & -645 & 20 \\
\hline $\begin{array}{l}\text { Absence of the magnetic field } \\
\text { after 30 d of immersion }\end{array}$ & -135 & 33 \\
\hline
\end{tabular}

Other authors observed the presence of the AlSiFe, $\mathrm{AlFe}, \mathrm{AlFeMn}$, and AlSi phases in alloys with the compositions similar to the alloys presented in this study. ${ }^{17-19}$ Okeoma Kelechukwu et al. ${ }^{18}$ observed the AlFeMn and $\mathrm{MnFe}$ particles in the AA8011 aluminum alloy containing $0.1 \%$ of Mn used as a packaging foil. They noticed that the presence of the Fe and Si elements in the material support the precipitation of the dispersoids and decreases the solubility of $\mathrm{Mn}$ in a solid solution. They also noticed that the precipitation of $\mathrm{Mn}$ and other inter- 
metallic particles definitely causes changes in the morphology and electrochemical stability of the material system. Sanders Jr. et al. ${ }^{17}$ noticed that AA8xxx foils containing manganese in the order of $0.5 \%$ promote the formation of $(\mathrm{Fe}, \mathrm{Mn}) \mathrm{Al}_{6}$ intermetallic particles with the average diameter of $0.11 .5 \mu \mathrm{m}$. Paes et al. ${ }^{20}$ observed the formation of $(\mathrm{Fe}, \mathrm{Mn}) \mathrm{Al}_{\mathrm{n}}$ and $(\mathrm{Fe}, \mathrm{Mn}, \mathrm{Si}) \mathrm{Al}_{\mathrm{n}}$ in the AA8006 material. Mondolfo ${ }^{21}$ reported the presence of the $\mathrm{Al}_{3} \mathrm{Fe}$ and $\mathrm{AlFeSi}$ phases in the AA1050 aluminum. Allen et al. ${ }^{22}$ reported three phases in $1 x x x$-series aluminum foils such as $\mathrm{FeAl}_{3}, \beta-\mathrm{FeSiAl}_{5}$ and $\alpha(\mathrm{AlFeSi})$.

After immersing the aluminum material in a corrosive environment, nobler phases in the aluminum matrix such as $\mathrm{AlSiFe}, \mathrm{AlFe}$, and $\mathrm{AlSi}^{23}$ promote the dissolution of aluminum in the matrix and the elements less noble than aluminum. However, $\mathrm{Al}_{\mathrm{x}} \mathrm{Fe}_{\mathrm{y}} \mathrm{Mn}_{\mathrm{z}}$ phases can promote the dissolution of aluminum in the matrix if the iron concentration in a phase is much higher than the manganese concentration, while on the contrary $\mathrm{Al}_{\mathrm{x}} \mathrm{Fe}_{\mathrm{y}} \mathrm{Mn}_{\mathrm{z}}$ is dissolved if the iron is nobler than the aluminum matrix and manganese is less noble than the matrix..$^{23-25}$ In such cases the behavior of intermetallic particles depends principally on the potential difference between the intermetallic-particle phase and the matrix. ${ }^{25}$

During cold working, precipitates and intermetallic particles are fractured and redistributed in bands along the rolling direction. ${ }^{26}$ The particles that contain copper and iron represent cathodic particles compaed to the matrix, supporting the matrix dissolution and the ones that contain magnesium or/and manganese represent anodic particles compared to the matrix, which dissolve preferentially. ${ }^{26}$ The presence of the cathodic particles increases the susceptibility to a localized corrosion. ${ }^{10}$ Iron- and copper-rich phases are catalytic sites for cathodic reactions and the sites for pits nucleation.

Using scanning electron microscopy after $30 \mathrm{~d}$ of immersion, localized attacks were observed on the surfaces of several aluminum foils (Figures 7a to 7d), together with the destruction of the oxide-protective film, probably due to the pitting and dissolution of aluminum due to the chloride adsorption to the surfaces, thus facilitating an aluminum oxidation of the $\mathrm{A}^{3+}{ }^{3+}$ ions. ${ }^{27} \mathrm{We}$ observed the traces of aluminum oxide $\mathrm{Al}_{2} \mathrm{O}_{3}$ on the packaging foil for domestic use after the immersion (Table 4). All the aluminums made from the primary or recycled aluminum contain iron. Ambat et al. ${ }^{9}$ showed that the presence of a small concentration of iron in aluminum alloys leads to a localized corrosion due to pitting. Our results (Figure 7) are in good agreement with Ambat et al. ${ }^{9}$ The presence of chloride ions has a harmful effect on the passive-layer formation. It leads to an instability of passivation causing a localized corrosion. The material structure, composition and defects, and the oxide structure, composition and thickness have very significant influences on the aluminum-packagingfoil corrosion.

Table 4: EDS analysis of a foodstuff foil in a roll (aluminum for domestic use)

Tabela 4: EDS-analiza navite folije za živila (aluminij za domačo uporabo)

\begin{tabular}{|c|c|c|c|c|c|c|}
\hline \multicolumn{2}{|c|}{$\begin{array}{l}\text { Before } \\
\text { corrosion }\end{array}$} & $\begin{array}{l}\text { Ele- } \\
\text { ment }\end{array}$ & $\begin{array}{c}\text { Energy } \\
(\mathrm{keV})\end{array}$ & $\begin{array}{c}\text { Concen- } \\
\text { tration in } \\
\text { mass } \\
\text { fractions } \\
(w / \%)\end{array}$ & $\begin{array}{l}\text { Concen- } \\
\text { tration in } \\
\text { amount } \\
\text { fractions } \\
(x / \%)\end{array}$ & $\begin{array}{c}\text { Error } \\
(\%)\end{array}$ \\
\hline & & $\mathrm{Al}$ & 1.486 & 100.00 & 100.00 & 0.38 \\
\hline & & $\mathrm{O}$ & - & 0 & 0 & - \\
\hline \multirow{4}{*}{$\begin{array}{l}\text { After } 3 \\
\text { months } \\
\text { of corro- } \\
\text { sion }\end{array}$} & \multirow{2}{*}{$\begin{array}{c}\text { Zone } \\
1\end{array}$} & $\mathrm{Al}$ & 1.486 & 95.96 & 93.68 & 1.97 \\
\hline & & $\mathrm{O}$ & 0.525 & 4.04 & 6.62 & 5.60 \\
\hline & \multirow{2}{*}{$\begin{array}{c}\text { Zone } \\
2\end{array}$} & $\mathrm{Al}$ & 1.486 & 93.79 & 89.96 & 1.93 \\
\hline & & $\mathrm{O}$ & 0.525 & 6.21 & 10.4 & 5.30 \\
\hline
\end{tabular}

The corrosion microstructures of the cheese aluminum packaging foil in the $3 \%$ of mass fractions of $\mathrm{NaCl}$ solution after $8 \mathrm{~d}$ of immersion with or without a weak magnetic field are compared. The effect of a weak magnetic field on the morphology corrosion was observed. In the case of the absence of the magnetic field, the corrosion is located only in certain areas on the
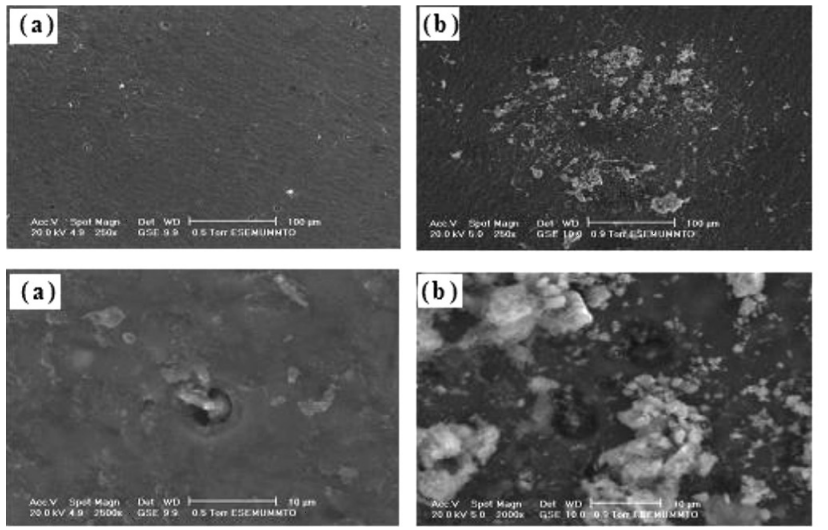
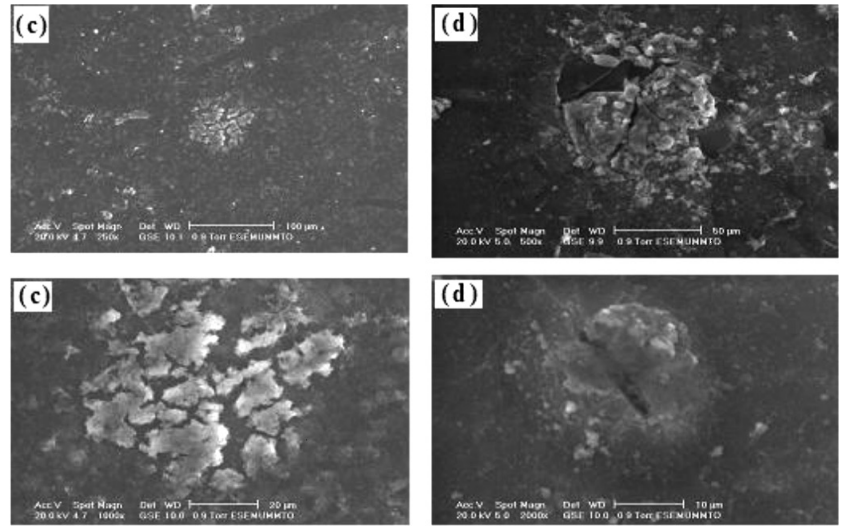

Figure 7: Morphologies of the corrosion of various aluminum packaging foils after $30 \mathrm{~d}$ of corrosion in a solution of $0.3 \%$ of mass fractions of $\mathrm{NaCl}$ in the absence of the magnetic field: a) for domestic use, b) for chocolate, c) for cheese, d) for drugs

Slika 7: Morfologija korozije različnih aluminijevih embalažnih folij po 30-dnevni koroziji v raztopini $0,3 \% \mathrm{NaCl}$ in ob odsotnosti magnetnega polja: a) za gospodinjstvo, b) za čokolado, c) za sir, d) za zdravila 
corroded-material surface, but with the samples corroded under a weak magnetic field, the corrosion affected a more significant area (Figure 6). At room temperature, iron is ferromagnetic; this characteristic can explain some changes in the morphology and the corrosion kinetics under a weak permanent magnetic field. Several authors: Devos et al. ${ }^{28}$ and Nikolić ${ }^{29}$ showed that an imposed magnetic field equal to or more than $0.3 \mathrm{~T}$ in the study of Devos et al. ${ }^{28}$, and equal to $39788 \mathrm{~A} / \mathrm{m}$ in the study of Nikolić ${ }^{29}$ causes various effects, in particular, on the morphologies and structures of deposed metals or alloys. However, the magnetic field used was not permanent and the intensity of the field was not weak. The authors attribute these effects to the Lorentz force of electrolytic processes; this force affects the migration of ions and induces a convective flow of the electrolyte close to the electrode surface. This idea can also explain the obtained results and the difference between the corrosions with and without a weak magnetic field because the ion migration and the convective flow affect the corrosion phenomena.

Aluminum-packaging-foil environment (food and drugs) is rich in oxygen, acid and salt. Localized corrosion attacks occur due to galvanic coupling between the nobler particles and the more active aluminum-alloy matrix, and between the less noble particles and the other nobler phases (the aluminum matrix and nobler particles). A cathodic reaction of the oxygen and hydrogen reduction occurs on the cathodic precipitate surface: ${ }^{10,30}$

$$
\begin{gathered}
\mathrm{O}_{2}+2 \mathrm{H}_{2} \mathrm{O}+4 \mathrm{e}^{-} \longrightarrow 4 \mathrm{OH}^{-} \\
2 \mathrm{H}^{+}+2 \mathrm{e} \longrightarrow \mathrm{H}_{2}
\end{gathered}
$$

The main anodic process, which happens in parallel with the cathodic reaction, is the dissolution of the aluminum matrix: ${ }^{10}$

$$
\mathrm{Al} \longrightarrow \mathrm{Al}^{+3}+3 \mathrm{e}^{-}
$$

In the concave environment, we observed the pitting of some aluminum packaging foil; the dissolution of intermetallic particles with a round shape can explain this observation that was also well discussed by $\mathrm{Seri}^{30}$. If the less noble intermetallic particles are dissolved, they enter the corrosion solution. If this solution is food or a drug, it becomes toxic.

The investigation of the surface composition of the aluminum packaging foil before and after three months of corrosion in the $0.3 \%$ of mass fractions of $\mathrm{NaCl}$ solution, using an EDS analysis, revealed that the surface of the aluminum foil for domestic use (foodstuff packaging in a roll) was not varnished because the concentration of aluminum was $100 \%$ before the corrosion (Table 4). After three months of the packaging-foil corrosion, an aluminum oxide film was developed because the oxygen concentration was increased (Table 4). The EDS analysis of the foils intended for drugs, cheese and chocolate show that the foils were varnished, but the varnish film did not completely cover the aluminum surface because the analysis before the corrosion showed the presence of aluminum on the surface (Tables 5 to 7). Part of the varnish dissolved after three months of the corrosion in the $0.3 \%$ of mass fractions of $\mathrm{NaCl}$ solution as the analysis also showed an increase in the aluminum concentration on the surface (Tables 5 to 7). Thus, the aluminum surface became partially naked. This situation is almost the same as in the case of the aluminum for domestic use (Table 4).

\begin{tabular}{|c|c|c|c|c|c|}
\hline \multirow{5}{*}{$\begin{array}{l}\text { Aluminum } \\
\text { foil before } \\
\text { corrosion }\end{array}$} & $\begin{array}{l}\text { Ele- } \\
\text { ment }\end{array}$ & $\begin{array}{c}\text { Energy } \\
(\mathrm{keV})\end{array}$ & $\begin{array}{l}\text { Concen- } \\
\text { tration in } \\
\text { mass } \\
\text { fractions } \\
(w / \%)\end{array}$ & $\begin{array}{l}\text { Concen- } \\
\text { tration in } \\
\text { amount } \\
\text { fractions } \\
(x / \%)\end{array}$ & $\begin{array}{c}\text { Error } \\
(\%)\end{array}$ \\
\hline & $\mathrm{Al}$ & 1.486 & 15.05 & 7.86 & 0.31 \\
\hline & $\mathrm{O}$ & 0.525 & 25.33 & 22.30 & 0.70 \\
\hline & $\mathrm{C}$ & 0.277 & 59.54 & 69.81 & 0.17 \\
\hline & $\mathrm{Cl}$ & 2.621 & 0.08 & 0.03 & 0.42 \\
\hline \multirow{3}{*}{$\begin{array}{l}\text { Aluminum } \\
\text { foil after } 3 \\
\text { months of } \\
\text { corrosion }\end{array}$} & $\mathrm{Al}$ & 1.486 & 31.60 & 17.64 & 0.68 \\
\hline & $\mathrm{O}$ & 0.525 & 10.81 & 10.18 & 3.11 \\
\hline & $\mathrm{C}$ & 0.277 & 57.58 & 72.19 & 1.25 \\
\hline
\end{tabular}

Table 5: EDS analysis of a foil for drugs Tabela 5: EDS-analiza folije za zdravila

\begin{tabular}{|c|c|c|c|c|c|}
\hline \multirow{5}{*}{$\begin{array}{l}\text { Aluminum } \\
\text { foil before } \\
\text { corrosion }\end{array}$} & $\begin{array}{l}\text { Ele- } \\
\text { ment }\end{array}$ & $\begin{array}{c}\text { Energy } \\
(\mathrm{keV})\end{array}$ & $\begin{array}{l}\text { Concentra- } \\
\text { tion in } \\
\text { mass } \\
\text { fractions } \\
(w / \%)\end{array}$ & $\begin{array}{l}\text { Concen- } \\
\text { tration in } \\
\text { amount } \\
\text { fractions } \\
(x / \%)\end{array}$ & $\begin{array}{c}\text { Error } \\
(\%)\end{array}$ \\
\hline & $\mathrm{Al}$ & 1.486 & 0.68 & 0.37 & 0.13 \\
\hline & $\mathrm{O}$ & 0.525 & 43.98 & 40.73 & 0.24 \\
\hline & $\mathrm{C}$ & 0.277 & 43.85 & 54.09 & 0.11 \\
\hline & $\mathrm{Cl}$ & 2.621 & 11.49 & 4.80 & 0.16 \\
\hline \multirow{3}{*}{$\begin{array}{l}\text { Aluminum } \\
\text { foil after } 3 \\
\text { months of } \\
\text { corrosion }\end{array}$} & $\mathrm{Al}$ & 1.486 & 52.61 & 17.64 & 3.61 \\
\hline & $\mathrm{O}$ & 0.525 & 13.38 & 10.18 & 3.94 \\
\hline & $\mathrm{C}$ & 0.277 & 34.01 & 72.19 & 1.10 \\
\hline
\end{tabular}

Table 6: EDS analysis of a foil for cheese

Tabela 6: EDS-analiza folije za sir

\begin{tabular}{|c|c|c|c|c|c|}
\hline \multirow{5}{*}{$\begin{array}{l}\text { Aluminum } \\
\text { foil before } \\
\text { corrosion }\end{array}$} & $\begin{array}{l}\text { Ele- } \\
\text { ment }\end{array}$ & $\begin{array}{c}\text { Energy } \\
(\mathrm{keV})\end{array}$ & $\begin{array}{l}\text { Concentrati } \\
\text { on in mass } \\
\text { fractions } \\
(w / \%)\end{array}$ & $\begin{array}{l}\text { Concen- } \\
\text { tration in } \\
\text { amount } \\
\text { fractions } \\
(x / \%)\end{array}$ & $\begin{array}{c}\text { Error } \\
(\%)\end{array}$ \\
\hline & $\mathrm{Al}$ & 1.486 & 23.96 & 18.20 & 0.16 \\
\hline & $\mathrm{O}$ & 0.525 & 04.96 & 6.36 & 0.46 \\
\hline & $\mathrm{C}$ & 0.277 & 30.43 & 51.93 & 0.58 \\
\hline & $\mathrm{Cl}$ & 2.621 & 40.65 & 23.50 & 0.23 \\
\hline \multirow{3}{*}{$\begin{array}{l}\text { Aluminum } \\
\text { foil after } 3 \\
\text { months of } \\
\text { corrosion }\end{array}$} & $\mathrm{Al}$ & 1.486 & 81.44 & 69.53 & 1.62 \\
\hline & $\mathrm{O}$ & 0.525 & 1071 & 15.42 & 4.57 \\
\hline & $\mathrm{C}$ & 0.277 & 7.87 & 15.06 & 9.06 \\
\hline
\end{tabular}

Table 7: EDS analysis of a foil for chocolate

Tabela 7: EDS-analiza folije za čokolado 


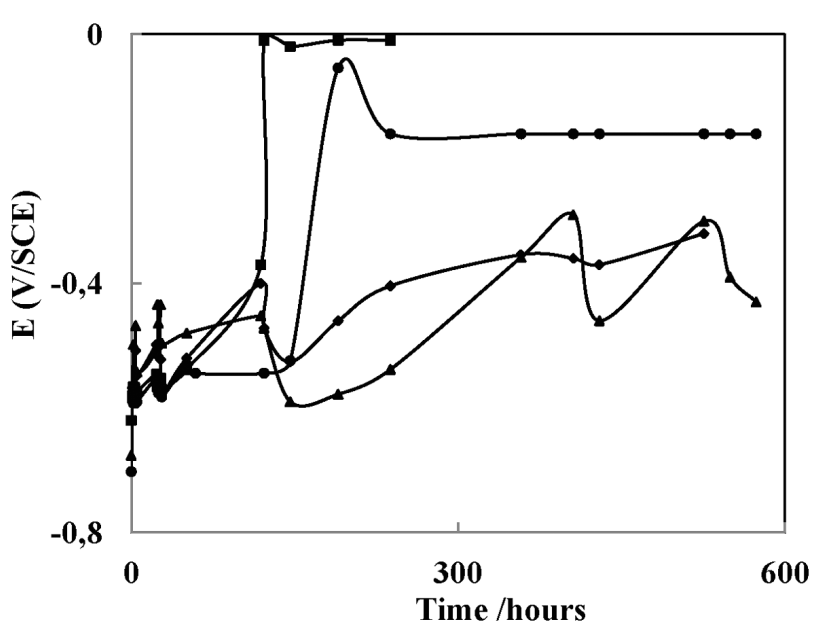

Figure 8: Open-circuit potential in the absence of the magnetic field for aluminum packaging foils for: $\bullet$ drugs, $\boldsymbol{\Delta}$ domestic use, $\bullet$ chocolate, cheese

Slika 8: Potencial odprtega kroga ob odsotnosti magnetnega polja pri aluminijevi embalažni foliji za: $\bullet$ zdravila, $\boldsymbol{\Delta}$ gospodinjstvo, $\bullet$ čokolado, $\mathbf{a}$ sir

\subsection{Kinetics of the corrosion and the dissolution of the aluminum packaging foil}

The results considered (Figure 8) show differences between the corrosion kinetics for different aluminum packaging foils. For an open-circuit potential, the taken measurements present a high degree of dispersion of values. The initial open-circuit potential, the passivation open-circuit potential and the passivation time are different for different aluminum packaging foils. The differences are due to the chemical compositions of the matrices and the presence of different kinds of precipitates and intermetallic particles in the alloy matrices, and the differences between the chemical compositions of different foils and the thermomechanical-treatment histories of the samples.

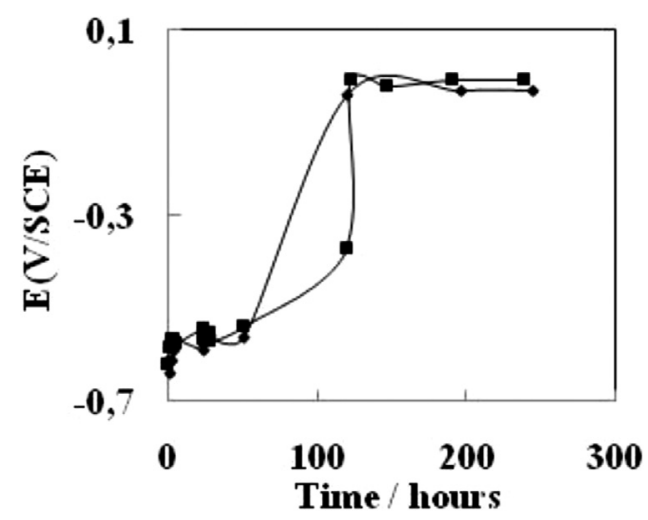

Figure 9: Corrosion-free potential of the aluminum packaging foil for cheese in a $0.3 \%$ of mass fractions of $\mathrm{NaCl}$ solution: $\mathbf{a b s e n c e}$ of the magnetic field, $\downarrow$ presence of a weak magnetic field

Slika 9: Korozijski prosti potencial aluminijeve embalažne folije za sir v raztopini $0,3 \% \mathrm{NaCl}$ : $\mathbf{\square}$ odsotnost magnetnega polja, $\downarrow$ prisotnost šibkega magnetnega polja

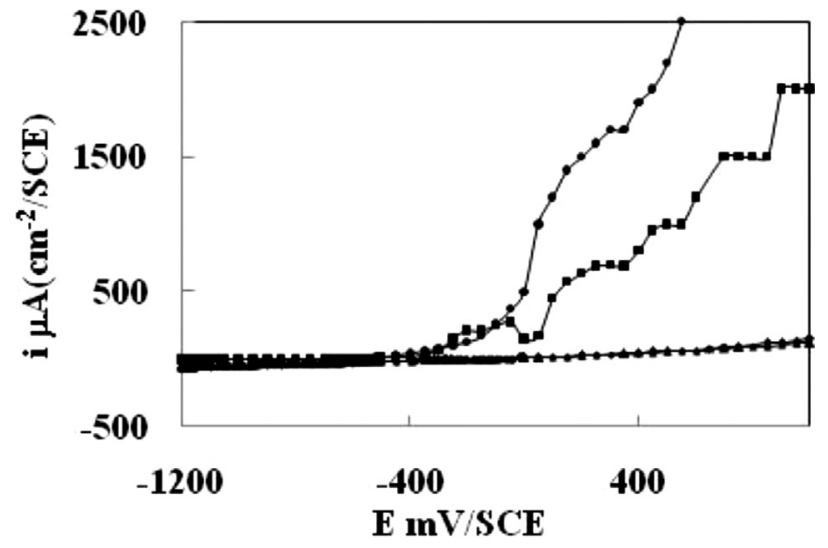

Figure 10: Polarization curves of the aluminum packaging foil for cheese in a $0.3 \%$ of mass fractions of $\mathrm{NaCl}$ solution: - presence of a weak magnetic field $1 \mathrm{~h}$ after the immersion, $\mathbf{a b s e n c e}$ of the magnetic field $1 \mathrm{~h}$ after the immersion, absence of the magnetic field 30 $\mathrm{d}$ after the immersion, $\boldsymbol{\Delta}$ presence of a weak magnetic field $30 \mathrm{~d}$ after the immersion

Slika 10: Polarizacijske krivulje aluminijeve embalažne folije za sir v raztopini $0,3 \% \mathrm{NaCl}$ : $\bullet$ prisotnost šibkega magnetnega polja $1 \mathrm{~h}$ po potopitvi, $\mathbf{a d s o t n o s t ~ m a g n e t n e g a ~ p o l j a ~} 1 \mathrm{~h}$ po potopitvi, $\bullet$ odsotnost magnetnega polja po 30-dnevnem namakanju, $\boldsymbol{\Delta}$ prisotnost šibkega magnetnega polja po 30-dnevnem namakanju

A complete electrochemical study of the aluminum packaging foil with and without a weak magnetic field was carried out only for the aluminum packaging foil intended for cheese, because cheese has to be preserved in a refrigerator. The open-circuit potential at the immersion time of the aluminum packaging foil for cheese is $-0.62 \mathrm{~V}$ in the absence of the magnetic field and -0.638 $\mathrm{V}$ in the presence of a weak magnetic field (Figure 9). The presence of a weak magnetic field seems to influence the corrosion kinetics in the first moments of

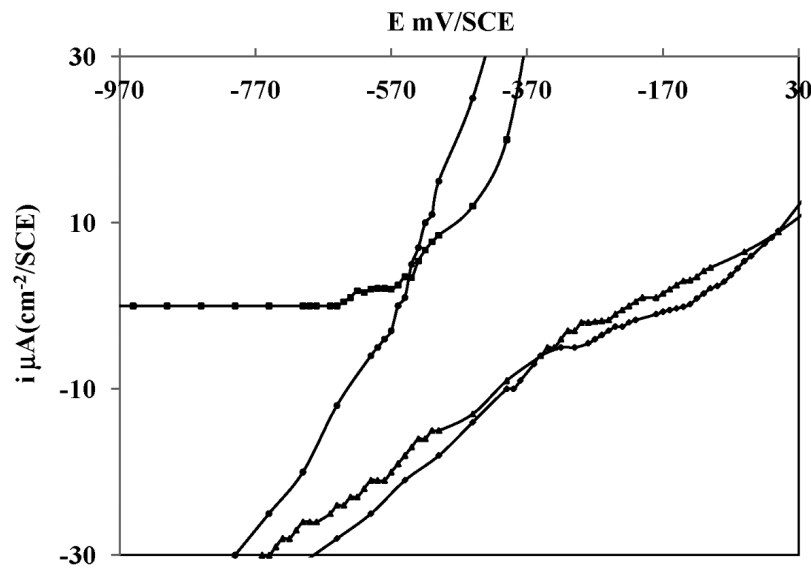

Figure 11: Magnifying-glass effect of polarization curves of the aluminum packaging foil for cheese in a $0.3 \%$ of mass fractions of $\mathrm{NaCl}$ solution: $\bullet$ presence of a weak magnetic field $1 \mathrm{~h}$ after immersion, absence of the magnetic field $1 \mathrm{~h}$ after immersion, $\downarrow$ absence of magnetic field $30 \mathrm{~d}$ after immersion, $\boldsymbol{\Delta}$ presence of weak magnetic field $30 \mathrm{~d}$ after immersion

Slika 11: Povečan izsek polarizacijske krivulje aluminijeve embalažne folije za sir v $0,3 \%$ raztopini $\mathrm{NaCl}$ - prisotnost šibkega magnetnega polja $1 \mathrm{~h}$ po namočitvi, $\mathbf{\square}$ odsotnost magnetnega polja $1 \mathrm{~h}$ po namočitvi, odsotnost magnetnega polja 30 dni po namočitvi, $\boldsymbol{\Delta}$ prisotnost šibkega magnetnega polja 30 dni po namočitvi 
immersion. The magnetic-field effect appears more visible later. The open-circuit potentials of the aluminum packaging foil for cheese with and without a magnetic field converge towards the same potential value of -0.03 $\mathrm{V}$ at the stationary regime and after $122 \mathrm{~h}$ of immersion (Figure 9).

Figure 10 represents polarization curves of the aluminum packaging foil intended for cheese and Figure 11 represents the magnifying-glass effect of the polarizations curves in the absence and presence of a weak magnetic field after $1 \mathrm{~h}$ and after $30 \mathrm{~d}$ of immersion. The presence of a weak magnetic field seems to increase the potential of corrosion at the beginning of corrosion and decrease it after $30 \mathrm{~d}$ of immersion (Figures $\mathbf{1 0}$ and 11; Table 3), but the passivation-current density seems to be increased at the beginning of corrosion in the presence of a magnetic field (Figures 9 and 10). We also observed that the presence of a weak magnetic field decreases the polarization resistance at the beginning and after $30 \mathrm{~d}$ of corrosion (Table 3), and decreases the passivation potential at the beginning (Figures $\mathbf{1 0}$ and 11). Thus, a weak magnetic field modifies the corrosion kinetics and aluminum-packaging-foil dissolution as soon as the corrosion starts. This result is in good agreement with the work of Devos et al. ${ }^{31}$, except that the minimum magnetic field applied by Devos et al. ${ }^{31}$ was a few hundreds of $\mathrm{mT}$.

The corrosion kinetics of aluminum packaging foils in the $0.3 \%$ of mass fractions of $\mathrm{NaCl}$ solution (Figures 8 to 10) compared to the work of $\mathrm{Seri}^{30}$ who studied the Al1.4\% Fe aluminum alloy, is different. This dissimilarity is due to the difference between the chemical compositions of the alloys or to the disparity between the surface residual stresses. ${ }^{7}$

\section{CONCLUSION}

Based on the study combining microscopy, X-ray diffraction, electrochemistry tests of aluminum packaging foil and the EDS results, the following conclusions were made:

- Various aluminum packaging foils underwent a localized corrosion in a $0.3 \%$ of mass fractions of $\mathrm{NaCl}$ solution, showing that the morphologies and the corrosion kinetics are different for different foils, depending on the chemical composition of the surface.

- The application of a weak magnetic field modifies the morphology and the kinetics of corrosion, decreasing the polarization resistance, the passivation potential and the corrosion potential at the beginning of corrosion. However, it increases the density of passivation current $1 \mathrm{~h}$ after the immersion of the cheese aluminum packaging foil, increases the corrosion potential after $1 \mathrm{~h}$ of corrosion and decreases the corrosion potential after $30 \mathrm{~d}$ of corrosion.
- X-ray diffraction results show the presence of a textured structure with a preferential orientation.

- The passivation of the aluminum packaging foil intended for cheese takes place after $122 \mathrm{~h}$ of corrosion in the absence and the presence of a weak magnetic field.

- The food packed in aluminum packaging foil can be contaminated by the aluminum metal.

- The EDS results show the presence of aluminum oxide on the surface after three months of corrosion.

\section{REFERENCES}

${ }^{1}$ M. Elboudjani, E. Ghali, A. Galibois, Corrosion par piqûre des alliages d'aluminium 5083-H321 et 6061-T651, Journal of Applied Electrochemistry, 18 (1988) 2, 257-267, doi:10.1007/BF01009273

${ }^{2}$ S. W. Dean, W. H. Anthony, Atmospheric corrosion of wrought aluminum alloys during a ten-year period, In: S. W. Dean, T. S. Lee (Eds.), Degradation of Metals in the Atmosphere, ASTM STP 965, American Society for Testing and Materials, Philadelphia 1988, 191-205

${ }^{3}$ F. L. McGeary, T. J. Summerson, W. H. Ailor, Atmospheric Exposure of Nonferrous Metals and Alloys-Aluminium: Seven-Year Data, Metal Corrosion in the Atmosphere, ASTM STP 435, American Society for Testing and Materials, Philadelphia 1968, 141-174

${ }^{4}$ I. T. E. Fonseca, N. Lima, J. A. Rodrigues, M. I. S. Pereira, J. C. S. Salvador, M. G. S. Ferreira, Passivity breakdown of Al 2024-T3 alloy in chloride solutions: attest of the point defect model, Electrochemistry Communications, 4 (2002) 5, 353-357, doi:10.1016/ S1388-2481(02)00273-4

${ }^{5}$ A. Aballe, M. Bethencourt, F. J. Botana, M. J. Cano, M. Marcos, Influence of the cathodic intermetallics distribution on the reproducibility of the electrochemical measurements on AA5083 alloy in $\mathrm{NaCl}$ solutions, Corrosion Science, 45 (2003) 1, 161-180, doi:10.1016/S0010-938X(02)00067-7

${ }^{6}$ E. J. Lee, S. I. Pyun, The effect of oxide chemistry on the passivity of aluminium surfaces, Corrosion Science, 37 (1995) 1, 157-168, doi:10.1016/0010-938X(94)00127-R

${ }^{7}$ N. Zazi, A. Bouabdallah, O. Aaboubi, J. P. Chopart, Pretreatment effects on the electrochemical responses for aluminium-magnesium alloy AA5083 corrosion behavior, Journal of Solid State Electrochemistry, 14 (2010) 9, 1705-1711, doi:10.1007/s10008-010-1021-0

${ }^{8}$ H. Ezuber, A. El-Houd, F. El-Shawesh, A Study on the corrosion behavior of aluminum alloys in seawater, Materials and Design, 29 (2008) 4, 801-805, doi:10.1016/j.matdes.2007.01.021

${ }^{9}$ R. Ambat, A. J. Davenport, G. M. Scamans, A. Afseth, Effect of iron-containing intermetallic particles on the corrosion behavior of aluminium, Corrosion Science, 48 (2006) 11, 3455-3471, doi:10.1016/j.corsci.2006.01.005

${ }^{10}$ K. A. Yasaku, M. L. Zheludkevich, S. V. Lamaka, M. G. S. Ferreira, Role of intermetallic phases in localized corrosion of AA5083, Electrochimica Acta, 52 (2007) 27, 7651-7659, doi:10.1016/j.electacta. 2006.12.072

${ }^{11}$ H. H. P. Fang, L. C. Xu, K. Y. Chan, Effects of toxic metals and chemicals on biofilm and biocorrosion, Water Research, 36 (2002) 19, 4709-4716, doi:10.1016/S0043-1354(02)00207-5

${ }^{12}$ T. Ramdé, L. Bonou, B. Guel, J. B. Legma, Comportement à la corrosion des alliages d'aluminium recyclés pour la confection de marmites, Journal de la Société Ouest-Africaine de Chimie, 026 (2008), 113-121

${ }^{13}$ R. A. Tacken, L. J. J. Janssen, Applications of magnetoelectrolysis, reviews of applied electrochemistry, Journal of Applied Electrochemistry, 25 (1995) 1, 1-5, doi:10.1007/BF00251257

${ }^{14}$ Federal Office for Radiation Safety, Word Health Organisation, Germany 1999 
${ }^{15}$ M. Marciszko, A. Baczmanski, K. Wierzbanowski, M. Wróbel, C. Braham, J. P. Chopart, A. Lodini, J. Bonarski, L. Tarkowski, N. Zazi, Application of multireflection grazing incidence method for stress measurements in polished $\mathrm{Al}-\mathrm{Mg}$ alloy and $\mathrm{CrN}$ coating, Applied Surface Science, 266 (2013) 1, 256-267, doi:10.1016/j.apsusc.2012. 12.005

${ }^{16}$ L. Muresan, L. Oniciu, M. Froment, G. Murin, Inhabitation of lead electrocrystallization by organic additives, Electrochimica Acta, 37 (1992) 12, 2249-2254, doi:10.1016/0013-4686(92)85119-6

${ }^{17}$ R. E. Sanders Jr., P. A. Hollinshead, E. A. Simielli, Industrial Development of Non-Heat Treatable Aluminum Alloys, Materials Forum, 28 (2004), 53-64

${ }^{18}$ B. Okeoma Kelechukwu, O. Owate Israel, E. Oguzie Emeka, M. Mejeha Ihebrodike, Effects of Heat Treatment on the Electrochemical Corrosion Behaviour of Aluminum Alloy AA8011 in $0.1 \mathrm{M} \mathrm{H}_{2} \mathrm{SO}_{4}$ Aqueous Acid Media, International Journal of Materials and Chemistry, 2 (2012) 4, 178-184, doi:10.5923/j.ijmc.20120204.11

${ }^{19}$ O. Keles, M. Dundar, Aluminum foil: Its typical quality problems and their causes, Journal of Materials Processing Technology, 186 (2007) 1, 125-137, doi:10.1016/j.jmatprotec.2006.12.027

${ }^{20}$ M. Paes, W. Gonçalves, E. J. Zoqui, Effect of grain refining and homogenizing treatment on Al-Fe-Mn-Si cast alloys, 18th International Congress of Mechanical Engineering, Ouro Preto, MG, Brazil, 2005

${ }^{21}$ L. F. Mondolfo, Aluminium Alloys: Structure and Properties, Butterworths, London 1976

${ }^{22}$ C. M. Allen, K. A. Q. O'Reilly, B. Cantor, P. V. Evans, Intermetallic phase selection in 1xxx Al alloys, Progress in Materials Science, 43 (1998) 2, 89-170, doi:10.1016/S0079-6425(98)00003-6

${ }^{23}$ N. Birbilis, R. G. Buchheit, Electrochemical Characteristics of Intermetallic Phases in Aluminum Alloys, Journal of The Electrochemical Society, 152 (2005) 4, 140-151, doi:10.1149/1.1869984
${ }^{24}$ A. J. Bard, R. Parsons, J. Jordan, Standard Potentials in Aqueous Solutions, IUPAC, Marcel Dekker, New York USA 1985

${ }^{25}$ Z. Szklarska-Smialowska, Pitting corrosion of aluminum, Corrosion Science, 41 (1999) 9, 1743-1767, doi:10.1016/S0010-938X(99) 00012-8

${ }^{26}$ F. Andreatta, M. M. Lohrengel, H. Terryn, J. H. W. de Wit, Electrochemical characterisation of aluminium AA7075-T6 and solution heat treated AA7075 using a micro-capillary cell, Electrochimica Acta, 48 (2003) 20, 3229-3247, doi:10.1016/S0013-4686(03) 00379-7

${ }^{27}$ S. Berrada, M. Elboujdaini, E. Ghali, Comportement électrochimique des alliages d'aluminium 2024 ET 7075 dans un milieu salin, Journal of Applied Electrochemistry, 22 (1992) 11, 1065-1071, doi:10.1007/ BF01029586

${ }^{28}$ O. Devos, A. Olivier, J. P. Chopart, O. Aaboubi, G. Maurin, Magnetic Field Effects on Nickel Electrodeposition, Journal of The Electrochemical Society, 145 (1998) 2, 401-405, doi:10.1149/ 1.1838276

${ }^{29}$ N. D. Nikolić, Some aspects of nickel electrodeposition in the presence of a magnetic field, Journal of the Serbian Chemical Society, 70 (2005) 10, 1213-1217, doi:10.2298/JSC0510213N

${ }^{30} \mathrm{O}$. Seri, The effect of $\mathrm{NaCl}$ concentration on the corrosion behavior of aluminum-containing iron, Corrosion Science, 36 (1994) 10, 1789-1803, doi:10.1016/0010-938X(94)90132-5

${ }^{31}$ O. Devos, O. Aaboubi, J. P. Chopart, E. Merienne, A. Olivier, J. Amblard, Magnetic Field Effects on Nickel Electrodeposition II. A Steady-State and Dynamic Electrochemical Study, Journal of The Electrochemical Society, 145 (1998) 12, 4135-4139, doi:10.1149/ 1.1838927 